\title{
Anna Jawor, Intymność cenzurowana. Panika moralna wokót rodziny na przykładzie rodzin nieheteronormatywnych w Polsce, Wydawnictwo Naukowe Scholar, Warszawa 2018, ss. 370
}

Polski dyskurs skoncentrowany na rodzinie jako jednostce społecznej i jako wartości jest, łagodnie rzecz ujmując, mocno spolaryzowany. Wydawać by się mogło, że taki temat — wspólny dla niemal wszystkich, niezależnie od wieku, wyznania, opcji politycznej, orientacji seksualnej czy statusu materialnego - powinien stanowić dobry grunt do debaty, skoro wszystkim zależy na „szczęściu rodzinnym”, „wartościach rodzinnych”, „dobrostanie rodziny”. Niestety, okazuje się, że owo szczęście dla każdego jest czymś innym, podobnie jak w polskiej debacie publicznej znajdziemy wiele definicji samej rodziny. Anna Jawor, autorka i redaktorka m.in. takich publikacji jak Wojna kultur. Czy "flaga tęczowa” wypiera „biato-czerwona” oraz Polska transformacja seksualna, nie obawia się podejmowania tematów aktualnych i trudnych, a takim terytorium badawczym jest dziś dyskurs familiologiczny. Sięgałam po nową książkę badaczki z perspektywy literaturoznawczyni zainteresowanej wizerunkiem rodziny w tekstach kultury, tak jak po wiele innych prac socjologicznych — interdyscyplinarność jest nieodzowna, jeśli chce się mieć możliwie pełny ogląd zagadnienia obejmującego tyle dziedzin życia. Intymność cenzurowana. Panika moralna wokót rodziny na przyktadzie rodzin nieheteronormatywnych $w$ Polsce wpisuje się w tendencje do mówienia o zjawiskach marginalnych lub marginalizowanych w kulturze czy życiu społecznym, jednocześnie opisując szeroko temat dotąd nieopracowany na większą skalę, a robi to w szczególnym momencie społeczno-politycznym.

Książka Anny Jawor ukazała się w 2018 roku, gdy debata publiczna w Polsce była świeżo po oswajaniu się z pojęciem płci kulturowej (w 2013 roku gender zostało przecież „Słowem roku”), raczej mniej niż bardziej skutecznym, i zaczynała się radykalizować — u władzy znajdowało się prawicowe stronnictwo polityczne, popularność zyskiwały ruchy narodowościowe, konserwatywny dyskurs podkreślał opozycję swój/obcy (uchodźcy, obcokrajowcy, 
innowiercy, osoby homoseksualne), sięgano po tematy polaryzujące społeczeństwo (jak prawo aborcyjne), rozpoczęły się strajki kobiet... Na początku 2021 roku jeszcze nie wiemy, czy owa radykalizacja osiągnęła apogeum. Moment wydania Intymności cenzurowanej jest znaczący, ponieważ autorka dokonywała operacji na żywym organizmie — analizy znajdujące się w książce dotyczą wypowiedzi publicznych z ostatnich 25 lat, w tym niedawnych w stosunku do daty wydania, a przecież temat rodzin nieheteroseksualnych wcale nie wygasł. „Problematyka ta jest szczególnie interesująca w Polsce, ponieważ jesteśmy jednym z ostatnich społeczeństw Zachodu, w których te sprawy nie są uregulowane, ale jako członek Unii Europejskiej państwo polskie będzie musiało się w końcu z nimi zmierzyć” — pisze Jawor we wstępie (7) ${ }^{1}$.

Zajmowanie się problemami społecznymi nie w ujęciu diachronicznym, lecz w postaci analiz żywego języka i zjawisk obecnych w danym momencie kultury wymaga od badacza określenia swojego miejsca w dyskursie. Autorka Intymności cenzurowanej nie próbuje konstruować w swojej narracji obiektywizmu — nie przekonuje czytelnika, że znajduje się poza opisywaną rzeczywistością i że nie ma własnych poglądów na dany temat. Włącza swoją pracę w obręb studiów kulturowych, sięgając po takie kategorie, jak płeć kulturowa, demokracja, tożsamość, reprezentacja czy tytułowa panika moralna. Pisze: „Badania w tym ujęciu w żadnym razie nie są obiektywne czy neutralne, bo też nie mogą takie być, są jak najbardziej polityczne. Nie mogą też być domknięte, wyczerpane, bo ich przedmioty z natury stanowią tylko fragment rzeczywistości, nieistniejący w próżni, pozostający pod ciśnieniem różnych innych przedmiotów i zjawisk, a w związku z tym są stale podatne na zmianę. Badacze z kolei nie udają, że żyją w innej rzeczywistości niż badany przedmiot i że są bezstronni” (12). Mogłoby się wydawać, że za takim postawieniem sprawy kryje się potrzeba badawczej asekuracji, lecz podkreślenie punktu widzenia autora jest tutaj konieczne — nie da się badać współczesnego nam świata bez podjęcia ryzyka opisywania niezamkniętych obszarów i ewoluujących zjawisk. Dokonanie krytycznej analizy paniki moralnej w odniesieniu do sytuacji rodzin nieheteronormatywnych i zmian w obrębie modelu rodziny stanowi wyraźnie wskazany cel publikacji (13). Anna Jawor deklaruje: „[... staram się przybliżyć ten fenomen na podstawie wypowiedzi publicznych, głównie tekstów publicystycznych rozpowszechnianych w naszym kraju, a skierowanych przeciwko rodzinom nieheteronormatywnym" (11), a odtworzenie dyskursu publicznego dotyczącego tej problematyki to zadanie wymagające dużej wrażliwości i zarazem zachowania koniecznego dystansu, bez wypierania się własnych przekonań, które każdy, również naukowiec, niewątpliwie ma. W jaki sposób badaczka realizuje ten mariaż krytycznej analizy i społecznej empatii?

Konceptem, na którym opiera się publikacja, jest teza, że stosunek do homorodzin można rozpatrywać przy użyciu kategorii paniki moralnej. „Pojęcie paniki moralnej sugeruje, że zagrożenie dotyczy czegoś uważanego za święte i nienaruszalne, a jednocześnie fundamentalne dla społeczeństwa” (18) - a w tym przypadku chodzi o rodzinę nuklearną jako wartość fundującą Polaków moralnie i o związki osób tej samej płci, które również miałyby tworzyć rodziny, mieć biologiczne lub adoptowane dzieci i w ten sposób zagrażać porządkowi społecznemu. Autorka, odwołując się do twórców pojęcia, przybliża je czytelnikowi: „U źródeł paniki moralnej stoi więc przerysowanie pewnych zjawisk, nadanie im uogólnionej i liczbowo znaczącej rangi oraz określenie ich jako odchylenie od normy, dewiację, coś, co jawi się jako zagrożenie dla istniejącego porządku społecznego” (22). Kluczową figurą są tutaj folks devils — raczej nietłumaczone na język polski „narodowe demony”, obiekty (osoby) mające

Wszystkie cytaty lokalizuję za wydaniem w formie e-booka. 
być przyczyną, sprawcami paniki; na przykład w Stanach Zjednoczonych na początku lat 80. XX wieku byli to homoseksualiści i narkomani uważani za sprawców epidemii HIV/AIDS (32). Mechanizm wskazywania folks devils przywodzi na myśl koncepcję kozła ofiarnego René Girarda, do którego zresztą słusznie odnosi się badaczka: zagrożona grupa w chwili kryzysu znajduje ofiarę, którą może obwinić o całe zło i wobec której kieruje zbiorową przemoc. Za Stanleyem Cohenem autorka wymienia pięć grup „aktorów” biorących udział w panice moralnej: media, opinię publiczną, siły porządku prawnego (law enforcement), polityków oraz działaczy-regulatorów (moral entrepreneurs) — media pojawiają się w tej grupie nie bez powodu, gdyż kreują kształt stosunków społecznych $(23 ; 30)$. Czy odpowiednio przedstawione przez te grupy rodziny nieheteronormatywne to nowe polskie folks devils?

Anna Jawor dowodzi swojej tezy, korzystając z techniki interpretacyjnej analizy tekstów kulturowych (Alan McKee) i opierając się na obszernym materiale badawczym. Obejmuje on zarówno gazety o profilu konserwatywnym, jak i pisma liberalne, a więc dwie strony poglądowej barykady. Ponadto: „[...] stenogramy z debat sejmowych, pisma Episkopatu Polski, treści kampanii społecznych oraz inne formy wypowiedzi publicystów, polityków, duchownych i innych aktorów zaangażowanych w badany dyskurs. Korzystałam również z ogólnopolskich badań opinii publicznej. Nie uwzględniłam for [sic!] internetowych, ponieważ nie spełniają one ani warunku reprezentatywności w sensie unikania ekstremów (Maison 2010), ani nie dostarczają odpowiedniego materiału [...]” (14). Książka została tak skomponowana, by przypominała ciągłą opowieść, w której fragmenty analityczne przeplatają się z opiniami samej autorki i przywoływanych badaczy — raz znajdujemy się bliżej sedna, czyli charakterystyki sytuacji homorodzin w Polsce, a raz poszerzamy perspektywę na Europę i świat albo odchodzimy dalej, w kierunku zjawisk luźniej związanych z tematem, jak sama rewolucja homoseksualna czy stosunek Polaków do islamu. Takie zaplanowanie treści ma swoje dobre i złe strony, gdyż co prawda pozwala dłużej utrzymać uwagę czytelnika i snuć narrację z wieloma tematycznymi kłączami, lecz chwilami zaciemnia główny przedmiot rozważań. Zarysowanie ogromnego tła badawczego dla tematyki stosunku Polaków do rodzin nieheteroseksualnych to zadanie iście karkołomne, ponieważ musiałoby obejmować m.in. obraz przemian modelu rodziny jako takiego, zarys polskiej sceny politycznej, opis relacji Polaków z różnego rodzaju „obcymi” (religijnie, etnicznie, seksualnie...), aspekty prawne zawierania małżeństw w Polsce i nie tylko, omówienie pojęcia narodu i tego, co się z nim wiąże, a wreszcie dopiero sytuację osób homoseksualnych. Intymność cenzurowana wszystkie te wątki porusza - oczywiście na 370 stronach niepodobna dokonać pełnej eksploracji tylu pól badawczych, więc każde z nich jest zarysowane i podparte źródłami. Początkowo może się wydawać, że kwestia islamu ma się nijak do polskiego dyskursu familiologicznego, jednak negatywne nastawienie większości Polaków (wniosek na podstawie danych CBOS-u) ma głęboko sięgające korzenie. „We współczesnych pluralistycznych społeczeństwach «Inny» to nie tylko gej, lesbijka, żyd czy Rom, to nie tylko Turek w Niemczech, Ukrainka w Polsce czy Algierczyk we Francji, to może być równie dobrze: słuchaczka Radia Maryja, staruszek, fanka Kelly Family, czytelniczka Gazety Wyborczej, obserwator ptaków czy młody przedstawiciel subkultury emo, bez względu na to, w ramach którego państwa i społeczeństwa przyszło mu żyć. Taka jest współczesna wielokulturowość, a kultura w coraz mniejszym stopniu jest tożsama ze zbiorowością ludzi żyjących w jej obrębie, dzielących jednakowy system normatywny, a raczej kojarzona jest z mnogością i różnorodnością sposobów ich życia, ich wyborów i znaków tożsamości. Kanon się rozsypał” (56) - zauważa badaczka. Dziś do głośnych panik moralnych można zaliczyć choćby te wokół działaczy 
ruchów „pro-choice”, aktywistów LGBT czy edukatorów seksualnych. Społeczny opór przed uznaniem rodzin nieheteroseksualnych za „normalne” to tylko jedna z wielu spornych kwestii.

Publiczne zaniepokojenie, poczucie wrogości w stosunku do postaci uosabiających rzekome zagrożenie, konsensus społeczny, nieproporcjonalność i nieprzewidywalność to pięć warunków paniki moralnej (143), których istnienie w związku z postrzeganiem homorodzin w Polsce udowadnia Anna Jawor w swojej publikacji. Publiczne zaniepokojenie jest wyraźnie widoczne w wypowiedziach polityków, dziennikarzy i innych znanych osób, które analizuje badaczka. Wrogość i stwarzanie poczucia zagrożenia przejawia się oczywiście w narracji mediów prawicowych i konserwatywnych polityków (akcentowanie odmienności, „nienormalności” homorodzin, nienazywanie ich rodzinami, powoływanie się na katolicyzm, podkreślanie „naturalności” ról kobiety i mężczyzny, łączenie homoseksualności z pedofilią itd.) - takich wypowiedzi w książce znajdziemy bardzo wiele. Przeciwwagę stanowią co prawda relacje z drugiej strony sceny politycznej, w których dominuje tendencja do przedstawiania nieheteronormatywnych rodzin jako „zwyczajnych, normalnych, z podobnym systemem wartości, troską o dzieci, porządkiem dnia i sposobami spędzania wolnego czasu jak wszystkie inne rodziny" (134). Jest to jednak protest stosunkowo nieśmiały, biorąc pod uwagę rozmach argumentacji strony przeciwnej i wspomniany konsensus społeczny. Jawor konsekwentnie i sukcesywnie wykazuje, że rzeczywiście mamy do czynienia z paniką moralną — demonizowaniem jednego zjawiska i uświęcaniem innego.

Nieproporcjonalność wrogości adresowanej do rodzin nieheteroseksualnych w stosunku do „zagrożenia”, jakie stanowią, zostaje w Intymności cenzurowanej poparta statystyką. Nie wiemy, ile dokładnie żyje w Polsce osób homoseksualnych ani ile mamy homorodzin, ponieważ: „Nie ma w Polsce żadnych danych dotyczących liczebności i struktury populacji osób LGBT. W ostatnim Spisie Powszechnym z 2011 roku nie uwzględniono par tej samej płci, a rodzina definiowana była jako «dwie lub większa liczba osób, które są związane jako mąż i żona, wspólnie żyjący partnerzy (kohabitanci) — osoby płci przeciwnej lub jako rodzic i dziecko»” (100). Z szacunków wynika, że środowisko LGBT w Polsce tworzy ok. $2 \mathrm{mln}$ osób, a tylko 8,5\% z nich ma dzieci (131). Czy zatem rzeczywiście „normalna” rodzina powinna czuć się zagrożona? Autorka idzie dalej, pochylając się nad kwestią owej normalności, czyli przewagi rodziny nuklearnej w Polsce. Obok nielicznych homorodzin spotykamy przecież inne alternatywne modele, o wiele liczniejsze, takie jak: kohabitacja, monoparentalność, LAT (Living Apart Together), DINKs (Double Income No Kids), wielorodzina (rodzina patchworkowa) czy model Friends (od tytułu popularnego serialu), „[...] a także jeśli rozejrzymy się dokoła tu i teraz, zobaczymy, że rodzina w tej najpopularniejszej formie, tzw. tradycyjna rodzina, jest zjawiskiem stosunkowo nowym i dość rzadkim. Życie uczuciowe i rodzinne ludzi jest niezwykle zróżnicowane i nie ma jednej naturalnej postaci” (62); ponadto: „[...] do rodziny włącza się na ogół więcej osób niż tylko męża lub żonę i dzieci. Polska nie jest społeczeństwem małych, dwupokoleniowych rodzin, żyjemy w środowisku krewniaczym przeciętny Polak potrafi wymienić aż 80 członków swojej rodziny” (80). Łatwo oszacować, że rodziny złożone wyłącznie z męża, żony i dzieci nie stanowią miażdżącej większości małżeństwa z biologicznymi dziećmi to zaledwie połowa rodzin w Polsce (dane z roku 2011).

Ważną część publikacji stanowią diagnozy stawiane przez Annę Jawor, wplecione w narrację analityczną. Jeżeli nie homorodziny zagrażają nuklearnemu modelowi, to co? Badaczka stara sięodpowiedzieć na to pytanie, by dowieść, że negatywny stosunek do nieheteronormatywnych rodzin to wynik paniki moralnej. Pisze: „Powstają nowe instytucje, jak związek partnerski, do 
osłony tych samych wartości rodzinnych, ale istniejących w nowych kontekstach społecznych. Te instytucje nie wynikają z tradycji, ale dyscyplinują i określają nowe style życia, kontynuujące tradycyjne wartości, tylko że w nowych społecznych okolicznościach, które zachodzą niezależnie od woli potencjalnych członków rodziny” (254). I dalej: „Rodzina jako taka, jak wszystko, adaptuje się do ponowoczesnych warunków życia społecznego, co wcale nie powoduje jej zaniku, a większą podmiotowość w jej konstruowaniu, stopień skomplikowania i zróżnicowanie. Ale badania wciąż wykazują to samo: rodzina (szczęście rodzinne, miłość rodzinna, udane życie rodzinne) stanowi dla Polek i Polaków najważniejszą wartość” (261). Rozpady małżeństw, samotne matki i niechęć do posiadania dzieci nie są nowym zjawiskami - nie pierwszy raz zapowiada się katastrofę demograficzną i zanik wartości moralnych, jednak dziś za kozły ofiarne czy folks devils obiera się homorodziny. W Intymności cenzurowanej padają ważkie pytania — o to, czy istnieje coś takiego jak „wzorzec kobiecości”, „wzorzec męskości” albo „wzorzec rodziny" i czy nie są to tylko fantazmaty oparte na stereotypach i utrwalane w kulturze.

Przyjęta metodologia umożliwia autorce eksponowanie własnej perspektywy, z czego zresztą badaczka skrzętnie korzysta. W niektórych stwierdzeniach wyraźnie widać jej ironiczny stosunek do konserwatywnego postrzegania polskości: „To jest Polska, która jawi się niczym etyczny i religijny monolit, w którym przeciwstawia się rodzime, wielowiekowe zakorzenienie w tradycji chrześcijańskiej wyjałowionemu aksjologicznie Zachodowi" (301-302) i dalej: „Polska jawi się niczym osobna cywilizacja, owszem - zachodnia, ale osobna, charakteryzująca się wyższością moralną, czystością, bohaterstwem i niezłomnie się broniąca" (302). Nie czynię z tego zarzutu, jednak są w pracy fragmenty, gdzie zaciera się granica między omawianiem cudzych słów a myślami samej autorki (zob.: 266; 296) — być może brakuje tutaj metatekstowych wtrętów, co utrudnia lekturę.

Dyskurs familiologiczny stanowi ogromny obszar, a sytuacja rodzin nieheteronormatywnych jest tylko jego niewielką częścią. Anna Jawor trafnie podsumowuje: „Przemiany tej mikrostruktury, jaką jest rodzina, są [...] pochodną przemian makrostrukturalnych, związanych z wyłanianiem się społeczeństwa ponowoczesnego ze wszystkimi jego cechami i procesami: globalizacją kulturową, zmierzchem patriarchatu, wyzwoleniem kobiet i przemianami męskości, wydłużeniem życia i poprawą jego jakości, wzrostem zamożności, rozwojem sieci komunikacji i telekomunikacji, postępującą sekularyzacją, w końcu elastycznością pracy, która zaciera granicę między czasem pracy a czasem rodziny, kosztem czasu rodziny" (83-84). Niewątpliwie Intymnośćcenzurowana podejmuje ważkie zagadnienia, niedostatecznie omówione i z pewnością wymagające dalszych badań, ale mające już solidną podstawę. Po tę publikację może sięgnąć nie tylko socjolog, ale także kulturoznawca, medioznawca czy literaturoznawca, który interesuje się szeroko pojętą „rodziną” — jest to bowiem wielowątkowa opowieść, trudna do ujęcia w abstrakcie, niezamknięta, za to wyjątkowo bliska przedmiotowi badań.

Tytułowa Intymność okazuje się całkowicie tej intymności pozbawiona, a to, co wydawałoby się prywatne - jest publiczne. Model demokratycznej rodziny, opierający się w założeniu na wzajemności, równowadze, na czystej relacji, o której pisał Giddens, bywa dziś różnie realizowany i często to rodziny nieheteronormatywne stanowią jego reprezentację, nie zaś uznawana za wzór polska rodzina nuklearna. Nasz rodzimy dyskurs familiologiczny, jak pokazuje Anna Jawor, nie jest gotowy na taką diagnozę. 